Zeszyty Naukowe Szkoły Głównej Gospodarstwa Wiejskiego w Warszawie

Problemy Rolnictwa Światowego tom 20 (XXXV), zeszyt 1, 2020: 78-87

DOI: 10.22630/PRS.2020.20.1.7

Arkadiusz Zalewski ${ }^{1}$

Instytut Ekonomiki Rolnictwa i Gospodarki Żywnościowej - Państwowy

Instytut Badawczy

\title{
Zmiany wartości zużytych nawozów i środków ochrony roślin w krajach Unii Europejskiej w latach 2010-2018
}

\section{Changes in the Value of Used Fertilizers and Plant Protection Products in the Countries of the European Union in the Years 2010-2018}

\begin{abstract}
Synopsis. Aktualnie duże znaczenie w agrobiznesie mają przemysłowe środki produkcji rolnej, w tym zwłaszcza nawozy mineralne oraz chemiczne środki ochrony roślin. W artykule próbowano przedstawić i porównać zmiany wartości zużytych nawozów i środków ochrony roślin w krajach Unii Europejskiej w latach 2010-2018. Badano zmiany wartości zużytych nawozów i środków ochrony roślin w przeliczeniu na 1 ha UR oraz zmiany udziału omawianych środków produkcji w zużyciu pośrednim. Stwierdzono, że wartość zużytych nawozów i środków ochrony roślin w przeliczeniu na 1 ha UR średnio w UE zwiększyła się. Wzrósł ich również udział w zużyciu pośrednim. W wyniku grupowania obiektów metodą Warda otrzymano 4 skupienia krajów, które różniły się pomiędzy sobą pod względem zaproponowanych cech, natomiast kraje, które tworzyły dane skupienie charakteryzowały się zbliżonymi wartościami zmiennych. Krajami w których zaobserwowano zarówno wyraźny wzrost wartości zużytych nawozów i środków ochrony roślin w przeliczeniu na jednostkę powierzchni jak również zdecydowane zwiększenie ich wartości w zużyciu pośrednim były: Litwa, Bułgaria i Estonia. Spadek popytu na omawiane środki produkcji wystapił natomiast w Belgii, Chorwacji, Słowenii, Danii, Finlandii oraz w Portugalii.
\end{abstract}

Słowa kluczowe: nawozy, środki ochrony roślin, Unia Europejska, metoda Warda

\begin{abstract}
Currently, agricultural means of production are of great importance in agribusiness, in particular mineral fertilizers and chemical plant protection products. The article attempts to present and compare changes in the value of used fertilizers and plant protection products in European Union countries in 2010-2018. Changes in the value of used fertilizers and plant protection products per 1 ha of UAA and changes in the share of these means of production in intermediate consumption were examined. It was found that the value of used fertilizers and plant protection products per 1 ha of UAA increased on average in the EU. Their share in intermediate consumption also increased. As a result of grouping objects using the Ward method, 4 clusters of countries were obtained, which differed in terms of the proposed features, while the countries that created the given cluster were characterized by similar values of variables. The countries where both a clear increase in the value of used fertilizers and plant protection products per unit area as well as a significant increase in their value in intermediate consumption were observed: Lithuania, Bulgaria and Estonia. However, a decline in demand for the discussed means of production occurred in Belgium, Croatia, Slovenia, Denmark, Finland and Portugal.
\end{abstract}

Key words: fertilizers, plant protection products, European Union, Ward method

JEL Classification: C38, Q12, Q14, Q19

\footnotetext{
${ }^{1}$ mgr inż., Zakład Badań Rynkowych IERiGŻ-PIB, ul. Świętokrzyska 20, 00-002 Warszawa, e-mail: arkadiusz.zalewski@ierigz.waw.pl; https://orcid.org/0000-0003-0471-9445
} 


\section{Wstęp}

Zagadnienia związane $\mathrm{z}$ rozwojem rynków środków produkcji dla rolnictwa są istotnym elementem analiz ekonomicznych prowadzonych w obszarze agrobiznesu. Jak zauważają Zalewski i Piwowar (2018) aktualnie duże znaczenie w agrobiznesie maja przemysłowe środki produkcji rolnej, w tym zwłaszcza nawozy mineralne oraz chemiczne środki ochrony roślin. Urban (2014) podkreśla ponadto, że współczesne rolnictwo charakteryzuje się wysokim zużyciem różnych środków produkcji pochodzenia przemysłowego.

Kopiński i Igras (2007) podkreślają, że nawożenie jest podstawowym czynnikiem plonotwórczym, a zużycie nawozów jednym z głównych wskaźników oceny intensywności gospodarowania. Przyjmuje się, że około 50\% wzrostu plonowania jest związane ze stosowaniem nawożenia mineralnego (Grześkowiak 1996). Warto jednak zaznaczyć, że nawozy mineralne stanowią również znaczący element struktury kosztów produkcji w gospodarstwach rolnych, co w istotny sposób limituje poziom ich zużycia. Jak zauważa Kopiński (2006) wydatki ponoszone przez producentów rolnych na zakup nawozów mineralnych należą do podstawowych $\mathrm{w}$ produkcji roślinnej. Z kolei, jak zauważa Golinowska (2009), środki do ochrony roślin nie są czynnikiem plonotwórczym, ale chronią plon i zapewniają efektywność innych nakładów. Piwowar (2018) podkreśla, że chemiczna ochrona roślin jest podstawowym zabiegiem agrotechnicznym w towarowych gospodarstwach rolnych prowadzących produkcję roślinną w systemie konwencjonalnym. Istotne jest również to, że intensyfikacja produkcji rolniczej prowadzi co prawda zazwyczaj do przyrostu i stabilizacji uzyskiwanych plonów, ale może również stwarzać liczne zagrożenia dla środowiska naturalnego (Jarecki, Bobrecka-Jamro 2013). Należy zatem mieć na uwadze, że tylko racjonalne stosowanie nawozów i środków ochrony roślin $\mathrm{w}$ rolnictwie, tj. uwzględnianie przez producentów rolnych zarówno kryteriów ekonomicznych, jak i ekologicznych, powoduje wzrost ilości i jakości płodów rolnych, przy ograniczeniu negatywnego wpływu na środowisko przyrodnicze (Piwowar 2013).

Problematyka rynku nawozowego oraz rynku środków ochrony roślin była podejmowana mi.n. w opracowaniach Piwowara (2012, 2018), Urbana (2014), Matyjaszczyk (2014), Malinowskiej i in. (2015), Jareckiego i Bobreckiej-Jamro (2013) i Zalewskiego $(2009,2013)$. Tendencje w popycie na omawiane środki do produkcji rolniczej $\mathrm{w}$ krajach UE to jednak zagadnienie raczej rzadko podejmowane $\mathrm{w}$ literaturze przedmiotu. Matyka (2013) analizował tendencje w zużyciu nawozów mineralnych w Polsce na tle krajów Unii Europejskiej w latach 2002-2010. Z jego badań wynika, że w analizowanym okresie zużycie nawozów w większości krajów wykazywało tendencję spadkową, a wzrost zużycia odnotowano jedynie w wybranych „nowych” krajach UE. Z badań Ossowskiej (2017) wynika natomiast, że w latach 2006-2015 nastapił wzrost zużycia nawozów azotowych łącznie w krajach UE, przy czym największy wzrost zużycia odnotowały kraje Bałtyckie oraz Bułgaria. Zalewski i Piwowar (2018) wskazują z kolei, że wartość zużytych nawozów w przeliczeniu na 1 ha UR średnio w krajach UE (wyrażona w cenach stałych z 2010 r.) zmalała ze 105 euro w 2005 r. do 98 euro w 2017 r.

Budzi zatem ciekawość jak zmieniało się zużycie nawozów i środków ochrony roślin w krajach UE w ostatnich latach. Celem artykułu była próba przedstawienia i porównania zmian wartości zużytych omawianych środków produkcji dla rolnictwa w krajach UE w latach 2010-2018. 


\section{Materiał i metodyka badań}

W pracy analizowano zmiany wartości zużytych w rolnictwie krajów Unii Europejskiej nawozów (łącznie z środkami poprawiającymi właściwości gleby) i środków ochrony roślin (zarówno w cenach bieżących, jak i cenach stałych z 2010 r.) w latach 20102018. Badano udział wartości zużytych w rolnictwie nawozów i środków ochrony roślin w zużyciu pośrednim. Poszczególne kraje UE pogrupowano pod względem zmian wartości zużytych agrochemikaliów w przeliczeniu na 1 ha UR oraz zmian udziału tych środków produkcji w zużyciu pośrednim w latach 2010-2018.

W pracy wykorzystano Rachunki Ekonomiczne dla Rolnictwa (RER) z bazy danych Eurostat. Uwzględniono pozycję „nawozy i środki wzbogacania gleby” (środki poprawiające właściwości gleby to nt. wapno, torf, muł piasek i pianki syntetyczne) oraz „środki ochrony roślin” (Rozporządzenie (WE) nr 138/2004 Parlamentu Europejskiego i Rady z dnia 5 grudnia 2003 r. dotyczące rachunków gospodarczych dla rolnictwa we Wspólnocie).

W celu pogrupowania krajów ze względu na zmiany w zużyciu nawozów i środków ochrony roślin w ujęciu wartościowym zastosowano analizę skupień. Polega ona na tym, że zbiór danych dzieli się na grupy w taki sposób, aby uzyskać skupienia, w których elementy $\mathrm{W}$ ramach tej samej grupy były do siebie podobne, a jednocześnie różniły się od elementów $\mathrm{z}$ innych grup. W pracy do pogrupowania krajów UE w skupienia zastosowano metode Warda, która należy do hierarchicznych metod klasyfikacji obiektów. Metody hierarchiczne są zaliczane do najprostszych i najczęściej używanych metod analizy skupień. Metodę Warda odróżnia od innych metod hierarchicznych to, że do oszacowania odległości między skupieniami wykorzystuje się podejście analizy wariancji. Algorytm tej metody polega na minimalizacji sumy kwadratów odchyleń wewnątrz skupień, czyli łączeniu dwóch skupień w taki sposób, aby dać najmniejszą łączną wariancję wewnątrzgrupową. Metoda Warda zapewnia zatem homogeniczność wewnątrz skupień i heterogeniczność między skupieniami. Metoda ta jest traktowana jako bardzo efektywna, chociaż zmierza do tworzenia skupień o małej wielkości. Co istotne pozwala ona na kontrolę nad wynikową liczbą grup oraz przedstawia najbardziej naturalne skupiska elementów (Ward 1963, Marek 1989, Młodak 2006).

Uwzględniając przesłanki merytoryczne wybrano cechy określające zmiany w zużyciu nawozów i środków ochrony roślin w krajach UE w latach 2010-2018. Zmienne opisujące zmiany wartości zużytych nawozów i środków ochrony roślin w przeliczeniu na 1 ha UR oraz zmiany udziału wartości nawozów i środków ochrony rośli w zużyciu pośrednim poddano weryfikacji statystycznej ze względu na współczynnik zmienności oraz współczynnik korelacji. Wartości tych współczynników mieściły się w wyznaczonych wartościach granicznych, dzięki czemu zmienne mogły być podstawą tworzenia skupień.

W celu sprowadzenia badanych cech do porównywalności poddano je standaryzacji, natomiast przy formowaniu skupień zastosowano odległość euklidesową. Utworzoną hierarchiczną strukturę skupień przedstawiono w formie drzewa skupień (dendrogramu). Wyniki poddano analizie porównawczej i opisowej. Do obliczeń wykorzystano program do statystycznej analizy danych Statistica 8.0. 


\section{Zmiany wartości zużytych nawozów i środków ochrony roślin w krajach Unii Europejskiej}

Łączna wartość zużytych nawozów i środków ochrony roślin w rolnictwie w krajach Unii Europejskiej wyrażona w cenach bieżących zwiększyła się w latach 2010-2018 o $18,2 \%$ do 29,9 mld euro. Wartość zużytych nawozów zwiększyła się o $11,3 \%$ do 17,0 mld euro, a środków do chemicznej ochrony roślin o $28,7 \%$ do 12,9 mld euro. Należy jednak podkreślić, że o ile w przypadku nawozów wzrost wartości zużycia wynikał wyłącznie $\mathrm{z}$ większego wolumenu, to $\mathrm{w}$ przypadku środków ochrony roślin był on wypadkową zarówno większego wolumenu zużycia jak i wyższych cen. Dla porównania łączna wartość zużytych nawozów i środków ochrony roślin wyrażona w cenach stałych (z 2010 r.) zwiększyła się w latach 2010-2018 o 16,2\%. W przeliczeniu na 1 ha UR wartość zużytych nawozów i środków ochrony roślin średnio w krajach UE (w cenach stałych) zwiększyła się ze 144,0 euro do 169,8 euro, tj. o 17,9\%. Można zatem stwierdzić, że zużycie nawozów i środków ochrony roślin w rolnictwie UE w latach 2010-2018 zwiększyło się zauważalnie.

Zmiany łącznej wartości zużytych nawozów i środków ochrony roślin w poszczególnych krajach UE w latach 2010-2018 były zróżnicowane. Zdecydowanie największy wzrost wartości (w cenach stałych z 2010 r.) odnotowano w Estonii (ponad 2-krotny), na Litwie (o 72,2\%), Łotwie (o 54,7\%), w Rumunii (o 49,5\%), Bułgarii (o 45,4\%) oraz w Polsce (o 42,2\%). Spadek wartości zużytych nawozów i środków ochrony roślin nastąpił natomiast m.in. w Belgii (o 28,0\%), w Finlandii (o 12,7\%), Portugalii (o 11,9\%), Chorwacji (o 8,0\%) i Danii (o 7,3\%), a wiec głównie w krajach „,starej” Unii (UE-15). W większości innych krajów UE-15 zmiany wartości zużycia były stosunkowo niewielkie. Całkowita wartość zużytych nawozów i środków ochrony roślin w krajach UE-15 zwiększyła się w analizowanym okresie o 10,7\%, podczas gdy w krajach UE-13 wzrosła o $38,4 \%$.

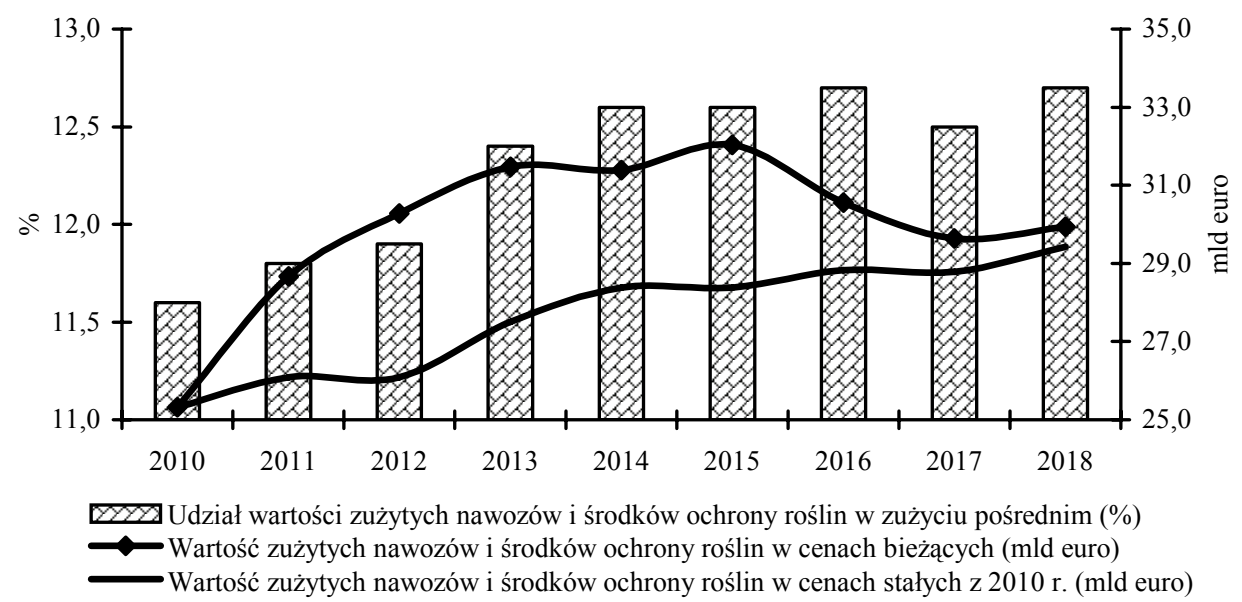

Rys. 1. Wartość zużytych nawozów i środków ochrony roślin (prawa oś) oraz ich udział w zużyciu pośrednim (lewa oś) w UE

Fig. 1. Value of used fertilizers and plant protection products (right axis of the chart) and their share in intermediate consumption (left axis of the chart) in the EU

Źródło: opracowanie własne na podstawie Rachunków Ekonomicznych dla Rolnictwa (RER) z bazy danych Eurostat. 


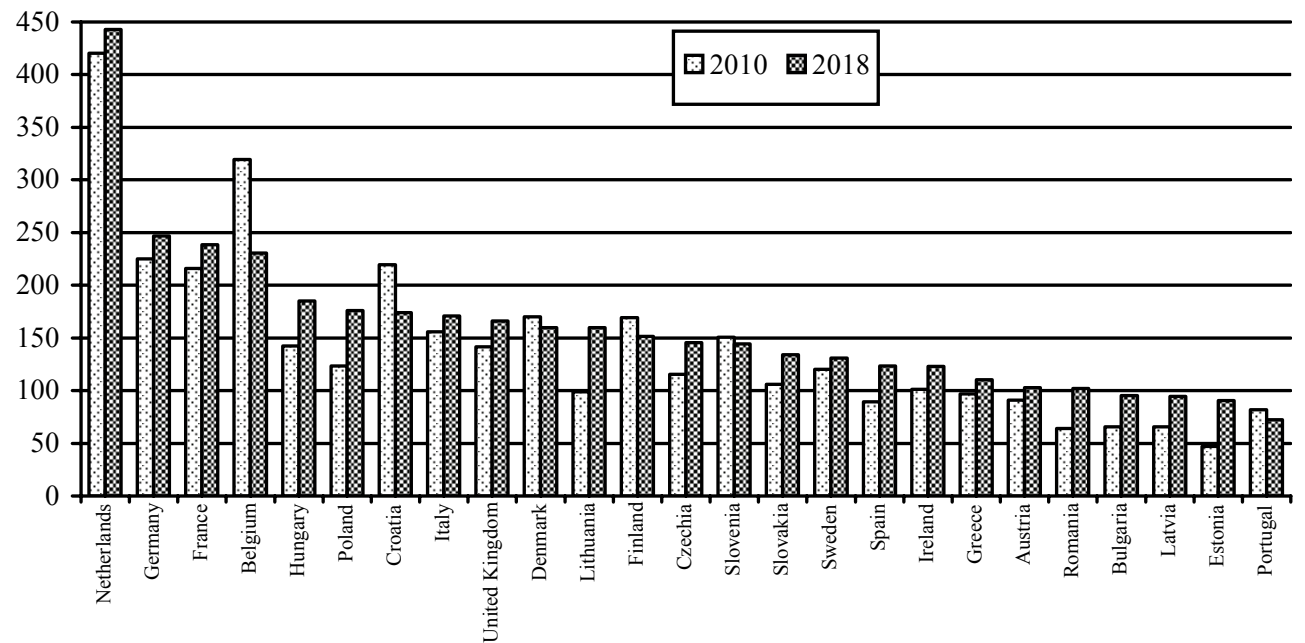

Rys. 2. Wartość zużytych nawozów i środków ochrony roślin w przeliczeniu na 1 ha UR w cenach stałych w wybranych krajach UE w 2010 r. i 2018 r.

Fig. 2. Value of used fertilizers and plant protection products per 1 ha of UAA in constant prices in selected EU countries in 2010 and 2018

Źródło: opracowanie własne na podstawie Rachunków Ekonomicznych dla Rolnictwa (RER) z bazy danych Eurostat.

W pewnym stopniu zmiany wartości zużytych przez producentów rolnych nawozów i środków ochrony roślin w krajach UE wynikały ze zmian powierzchni użytków rolnych. W przeliczeniu na 1 ha UR łączna wartość zużycia omawianych środków do produkcji rolniczej w Estonii zwiększyła się w latach 2010-2018 o 93,4\%, na Litwie o 61,4\%, w Rumunii o 51,9\%, w Bułgarii o 45,7\%, na Łotwie o 44,0\%, a w Polsce o 42,6\%. Wyraźny spadek odnotowano natomiast w Belgii (o 28,7\%) i w Chorwacji (o 20,7\%). Ponadto około $11 \%$ spadek wartości zużycia nawozów i środków ochrony roślin w przeliczeniu na jednostkę powierzchni odnotowano w Portugalii i Finlandii.

\section{Udział nawozów i środków ochrony roślin w zużyciu pośrednim w rolnictwie krajów Unii Europejskiej}

Przeciętny udział wartości zużytych nawozów i środków ochrony roślin w zużyciu pośrednim (obliczony dla cen stałych z 2010 r.) w UE w 2018 r. wyniósł 12,7\% i był o 1,1 pkt. proc. większy w stosunku do 2010 r. Oznacza to, że znaczenie nawozów i środków ochrony roślin w zużyciu pośrednim relatywnie wzrosło. Dla porównania w latach 2010-2018 przykładowo udział kosztów zakupu pasz dla zwierząt w zużyciu pośrednim nie zmienił się i wyniósł $37,1 \%$, udział energii i smarów zmalał z 11,5 do $10,9 \%$, udział usług rolniczych zwiększył się z 7,0 do 7,5\%, a nasion i sadzonek z 5,2 do $5,3 \%$. 


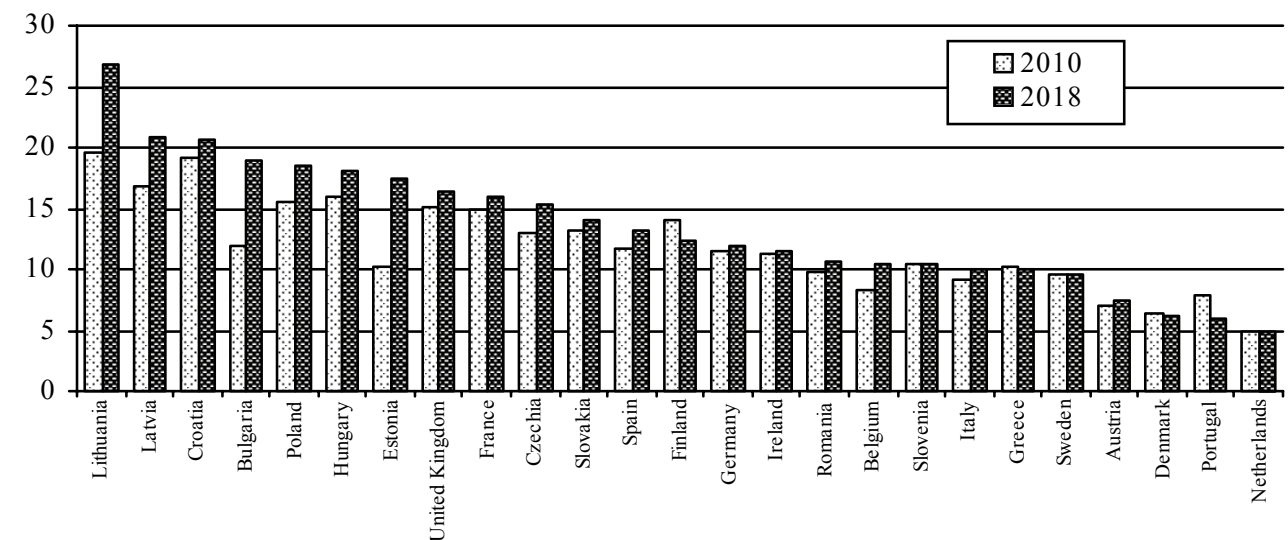

Rys. 3. Udział wartości nawozów i środków ochrony roślin w zużyciu pośrednim w 2010 i 2018 r. w wybranych krajach UE

Fig. 3. The share of the value of fertilizers and plant protection products in intermediate consumption in 2010 and 2018 in selected EU countries

Źródło: opracowanie własne na podstawie Rachunków Ekonomicznych dla Rolnictwa (RER) z bazy danych Eurostat.

Udział nawozów i środków ochrony roślin w zużyciu pośrednim był wyraźnie zróżnicowany pomiędzy poszczególnymi krajami UE. W 2018 r. zdecydowanie największą wartość tego wskaźnika odnotowano na Litwie (26,8\%), Łotwie $(20,8 \%)$, w Chorwacji $(20,6 \%)$, Bułgarii $(18,9 \%)$, Polsce $(18,5 \%)$ oraz na Węgrzech $(18,1 \%)$. Najmniejsza wartość badanego wskaźnika (poniżej 10\%) dotyczyła natomiast m.in. Szwecji, Austrii, Danii, Portugalii i Holandii. Należy przy tym podkreślić, że udział nawozów i środków ochrony roślin w zużyciu pośrednim w krajach UE-13 był większy niż w krajach UE-15. W tych pierwszych wyniósł w 2018 r. średnio $16,0 \%$, podczas gdy w krajach UE-15 było to przeciętnie $12,0 \%$.

Jak wspomniano wcześniej udział wartości zużytych nawozów i środków ochrony roślin w zużyciu pośrednim zwiększył się średnio w UE w latach 2010-2018 o 1,1 pkt. proc., przy czym wzrost ten był w poszczególnych krajach niejednakowy. Generalnie w krajach UE-13 był wyższy w porównaniu z krajami UE-15. W tej pierwszej grupie krajów wyniósł on przeciętnie 2,3 pkt. proc, natomiast w krajach UE-15 było to średnio 0,8\%. Zdecydowanie największy wzrost analizowanego wskaźnika odnotowano na Litwie (o 7,3 pkt. proc.), w Estonii (o 7,2 pkt. proc.) oraz Bułgarii (o 7,0 pkt. proc.). Wyraźny wzrost udziału nawozów i środków ochrony roślin w zużyciu pośrednim odnotowano ponadto na Łotwie (o 4,0 pkt. proc.) oraz w Polsce (o 3,0 pkt. proc.). Do krajów w których z kolei odnotowano spadek powyższego wskaźnika w latach 2010-2018 należy natomiast zaliczyć m.in. Portugalię, Finlandię, Danię, Szwecję oraz Grecję.

\section{Klasyfikacja krajów Unii Europejskiej ze względu na zmiany wydatków na nawozy mineralne i środki ochrony roślin w latach 2010-2018}

Optymalną liczbę skupień otrzymano poprzez odcięcie ramion dendrogramu tam, gdzie zaczynały się one robić dłuższe, a więc tam, gdzie odległości między skupieniami 


\section{A. Zalewski}

robiły się istotnie większe. Grupowanie obiektów metodą Warda pozwoliło na utworzenie 4 skupień krajów, które różniły się od siebie pod względem zaproponowanych cech. Natomiast kraje wchodzące w skład danego skupienia charakteryzowały się podobnymi wartościami zmiennych. Wyniki grupowania krajów metodą Warda przedstawiono na dendrogramie (rys. 4).

W pierwszym skupieniu znalazły się kraje ze zdecydowanie największym wzrostem udziału nawozów i środków ochrony roślin w zużyciu pośrednim w latach 2010-2018, tj. Litwa, Bułgaria oraz Estonia. W tych krajach odnotowano ponadto największym tempem wzrostu wartości zużytych nawozów i środków ochrony roślin w przeliczeniu na 1 ha UR. Można zatem stwierdzić, że wydatki ponoszone przez producentów rolnych na zakup analizowanych środki produkcji w latach 2010-2018 charakteryzowały się w tych krajach wyraźną tendencją wzrostową.

Do drugiego skupienia zakwalifikowanych zostało 8 krajów: Łotwa, Polska, Rumunia, Czechy, Węgry, Hiszpania, Wielka Brytania oraz Słowacja. Należy podkreślić, że większość z nich to kraje UE-13. Zarówno udział nawozów i środków ochrony roślin w zużyciu pośrednim, jak również wzrost wartości ich zużycia w przeliczeniu na 1 ha UR wykazywały w tych krajach w badanym okresie tendencję wzrostową. Tempo wzrostu było jednak zdecydowanie niższe w porównaniu z pierwszym skupieniem.

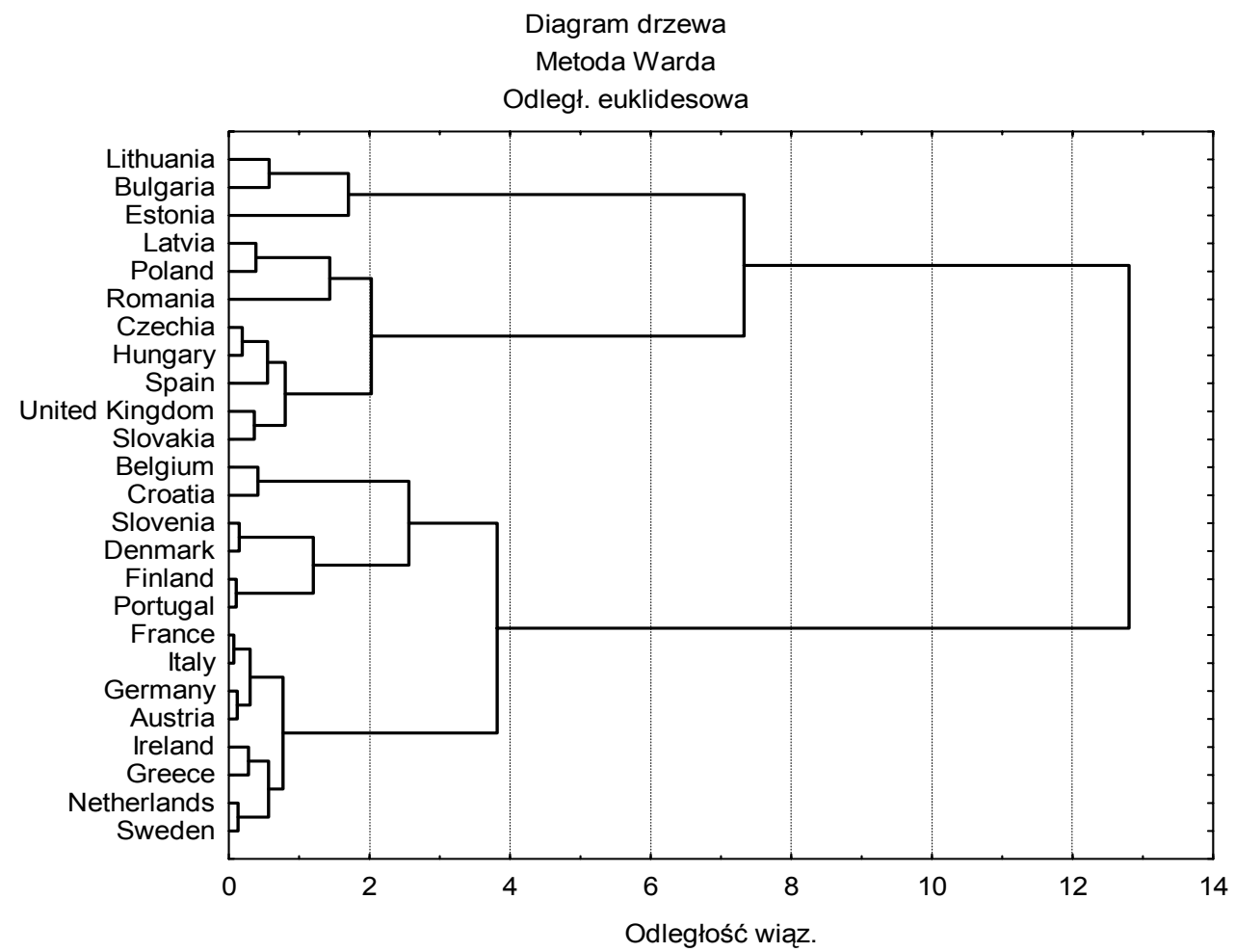

Rys. 4. Klasyfikacja krajów metodą Warda

Fig. 4. Country classification by the Ward method

Źródło: opracowanie własne na podstawie Rachunków Ekonomicznych dla Rolnictwa (RER) z bazy danych Eurostat. 
Trzecie skupienie obejmowało kraje, w których odnotowano stosunkowo niewielkie zmiany udziału nawozów i środków ochrony roślin w zużyciu pośrednim na przestrzeni analizowanych lat przy jednoczesnym spadku wartości zużytych nawozów i środków ochrony roślin $\mathrm{w}$ przeliczeniu na jednostkę powierzchni. W skupieniu tym znalazło się 6 krajów, przy czym 4 z nich to kraje UE-15. Do trzeciego skupienia zaliczono Belgię, Chorwację, Słowenię, Danię, Finlandię oraz Portugalie. Można stwierdzić, że w tych krajach wydatki na zakup nawozów i środków ochrony roślin w latach 2010-2018 zmniejszały się.

Tabela 1. Średnie wartości cech w skupieniach

Table 1. Average values of variables in clusters

\begin{tabular}{|c|c|c|c|c|c|}
\hline \multirow{2}{*}{ Cechy } & \multicolumn{4}{|c|}{ Skupienie } & \multirow{2}{*}{$\begin{array}{l}\text { Średnio } \\
\text { dla UE }\end{array}$} \\
\hline & I & II & III & IV & \\
\hline $\begin{array}{l}\text { Zmiana wartości zużytych nawozów i środków ochrony } \\
\text { roślin w przeliczeniu na } 1 \text { ha UR w latach } 2010-2018 \\
(2010=100)\end{array}$ & 166,8 & 135,5 & 86,6 & 111,6 & 117,9 \\
\hline $\begin{array}{l}\text { Zmiana udziału nawozów i środków ochrony roślin } \\
\text { w zużyciu pośrednim w latach 2010-2018 (pkt. proc) }\end{array}$ & 7,1 & 2,0 & 0,0 & 0,3 & 1,1 \\
\hline Liczba krajów w skupieniu & 3 & 8 & 6 & 8 & - \\
\hline
\end{tabular}

Źródło: opracowanie własne na podstawie Rachunków Ekonomicznych dla Rolnictwa (RER) z bazy danych Eurostat.

Do czwartego skupienia zaliczono wyłącznie kraje UE-15: Francję, Włochy, Niemcy, Austrię, Irlandię, Grecję, Holandię oraz Szwecję. W krajach tych nastąpił nieznaczny wzrost udziału nawozów i środków ochrony roślin w zużyciu pośrednim w latach 20102018. Ponadto nastapiło umiarkowane zwiększenie wartości zużytych nawozów i środków ochrony roślin $\mathrm{w}$ przeliczeniu na 1 ha UR, jednak był ono wyraźnie mniejsze w porównaniu z krajami z pierwszego i drugiego skupienia.

\section{Podsumowanie}

Z przeprowadzonych badań wynika, że w latach 2010-2018 łącznie w krajach Unii Europejskiej nastapiło zwiększenie wartości zużytych nawozów i środków ochrony roślin zarówno w cenach bieżących, jak również w cenach stałych z $2010 \mathrm{r}$. Wzrosła również wartość analizowanych środków produkcji dla rolnictwa w przeliczeniu na 1 ha UR, a także ich udział w zużyciu pośrednim.

Grupowanie obiektów metodą Warda pozwoliło na wyodrębnienie 4 grup krajów, które różniły się między sobą pod względem zmian wartości zużytych w rolnictwie nawozów i środków ochrony roślin w przeliczeniu na jednostkę powierzchni, a także zmian wartości omawianych środków produkcji w zużyciu pośrednim w latach 2010-2018. Z kolei kraje, które wchodził w skład danego skupienia charakteryzowały się podobnymi wartościami zmiennych objaśniających. Do krajów, w których odnotowano zdecydowanie największy wzrost wydatków na nawozy i środków ochrony roślin $\mathrm{w}$ analizowanym okresie zaliczono Litwę, Bułgarię oraz Estonię. Wyraźny wzrost odnotowano również w takich krajach, jak: Łotwa, Polska, Rumunia, Czechy, Węgry, Hiszpania, Wielka Brytania oraz Słowacja. Zmniejszenie wydatków na analizowane środki produkcji w latach 
2010-2018 odnotowano natomiast w Belgii, Chorwacji, Słowenii, Danii, Finlandii oraz Portugalii.

W pracy nie badano uwarunkowań zmian wydatków na nawozy i środki ochrony roślin w poszczególnych krajach UE. Można przypuszczać, że wyraźny wzrost wydatków na omawiane środki produkcji, który obserwowano w większości „nowych” krajów UE, był wynikiem szybkiego zwiększania intensyfikacji produkcji w związku z presją na wzrost plonowania. Warto jednak podkreślić że wyraźny wzrost intensyfikacji produkcji dotyczył przede wszystkim krajów, gdzie odbywał się on ze stosunkowo niskiej bazy wyjściowej. Spadek wydatków ponoszonych na nawozy i środki ochrony roślin w niektórych krajach UE-15 można natomiast wiązać z faktem, że zużycie tych środków produkcji osiągnęło już stosunkowo wysoki poziom i nie ma większych podstaw do dalszego wzrostu. Ponadto w tych krajach istotny odsetek stanowia duże obszarowo, nowoczesne gospodarstwa, w których wysokie plony są osiaggane dzięki wykorzystaniu postępu biologicznego, który pozwala na lepsze wykorzystanie czynników środowiskowych przy jednoczesnej optymalizacji czynników produkcji. Poza tym większą uwagę przywiązuje się do produkcji zdrowej żywności oraz do ograniczania negatywnego oddziaływania na środowisko. Zagadnienia te wymagają jednak dalszych badań.

\section{Literatura}

Grześkowiak, A. (1996). Nawozy mineralne we współczesnym rolnictwie. W: Nawożenie mineralne roślin uprawnych. Praca zbiorowa pod redakcją R. Czuby, Wyd. Zakłady Chemiczne „Police” S.A., Police.

Golinowska, M. (2009). Nakłady na chemiczną ochronę roślin w gospodarstwach wielkoobszarowych na początku XXI wieku (Chemical plant protection outlays in vast areas farming at the beginning of 21 st century). Journal of Agribusiness and Rural Development, 2(12), 53-60.

Igras, J., Kopiński, J. (2007). Zużycie nawozów mineralnych i naturalnych w układzie regionalnym. W: Sprawdzenie przydatności wskaźników do oceny zrównoważonego gospodarowania zasobami środowiska rolniczego w wybranych gospodarstwach, gminach i województwach, Studia i Raporty IUNG-PIB, nr 5, Puławy.

Jarecki, W., Bobrecka-Jamro, D. (2013). Zużycie środków do produkcji rolniczej w Polsce w kontekście retardacji przemian rolniczej przestrzeni produkcyjnej (The consumption of basic production means in Polish agriculture in respect to sustainable development of agriculture and rural areas). Inżynieria Ekologiczna, 34, 121-128.

Kopiński, J. (2006). Zróżnicowanie nawożenia jako miara intensywności produkcji roślinnej w regionach (Fertilization diversity as a measure of plant production intensity in regions). Wieś Jutra, 6, 15-17.

Malinowska, E., Jankowski, K., Wyrębek, H., Truba, M. (2015). Struktura sprzedaży i zużycia środków ochrony roślin w Polsce w latach 2000-2012 (Sale and use structure of plant protection products in poland in the years 2000-2012). Zeszyty Naukowe Uniwersytetu Przyrodniczo-Humanistycznego w Siedlcach, 104, 173-185.

Marek, T. (1989). Analiza skupień w badaniach empirycznych: metody SAHN, PWN, Warszawa.

Matyjaszczyk, E. (2014). Rynek środków ochrony roślin w Polsce w 2012 r. w ujęciu ilościowym i wartościowym (Market of plant protection products in Poland in the year 2012 in terms of volume and value). Roczniki Naukowe SERiA, 16(3), 177-182.

Matyka, M. (2013). Tendencje w zużyciu nawozów mineralnych w Polsce na tle krajów Unii Europejskiej (Trends in consumption of mineral fertilizers in Poland against the background of the European Union). Roczniki Naukowe SERiA, 15(3), 237-241.

Młodak, A. (2006). Analiza taksonomiczna w statystyce regionalnej, Difin, Warszawa.

Ossowska, M. (2017). Gospodarowanie nawozami azotowymi w Europie w kontekście ich wpływu na środowisko (Management of nitrogen fertilizers in Europe in terms of their impact on the environment). Zeszyty Naukowe. Inżynieria Środowiska, 167(47), 61-68.

Piwowar, A. (2012). Rynek środków ochrony roślin w Polsce w latach 2005-2009 (Market of plant protection products in Poland in 2005-2009). Journal of Agribusiness and Rural Development, 1(23), 85-93. 
Piwowar, A. (2013). Polski handel zagraniczny nawozami mineralnymi i środkami ochrony roślin w latach 2007-2011 (Market of plant protection products in Poland in 2005-2009). Roczniki Naukowe SERiA, 15(3), 267-271.

Piwowar, A. (2018). Chemiczna ochrona roślin we współczesnym rolnictwie w perspektywie ekonomicznej i ekologicznej - korzyści, koszty oraz preferencje. Wyd. Uniwersytetu Ekonomicznego we Wrocławiu, Wrocław.

Piwowar, A. (2018). The Consumption of Mineral Fertilizers and Herbicides in Poland Against the Background of the European Union. Problems of World Agriculture, 18(1), 194-202.

Urban, S. (2014). Zmiany w zużyciu środków ochrony roślin w Polsce i ich aspekty ekonomiczne (Changes in the use of plant protection means in Poland and their economic aspects). Roczniki Naukowe SERiA, 16(6), 505-509.

Ward, J.H. (1963). Hierarchical grouping to optimize an objective function. Journal of the American Statistical Association, 58

Zalewski, A., Piwowar, A. (2018). Światowy rynek nawozów mineralnych z uwzględnieniem zmian cen surowców i bezpośrednich nośników energii, Program Wieloletni 2014-2019, nr 80, IERiGŻ-PIB, Warszawa.

Zalewski, A. (2009). Sytuacja na rynku nawozów mineralnych w 2008 r. (Situation on the market of mineral fertilizers in 2008). Journal of Agribusiness and Rural Development, 2(12), 279-286.

Zalewski, A. (2013). Zmiany na rynku nawozów azotowych w Polsce w latach 2000-2010 (Changes in nitrogen fertilizers market in Poland in 2000-2010). Journal of Agribusiness and Rural Development, 4(30), 257-267.

Do cytowania / For citation:

Zalewski A. (2020). Zmiany wartości zużytych nawozów i środków ochrony roślin w krajach Unii Europejskiej w latach 2010-2018. Problemy Rolnictwa Światowego, 20(1), 78-87; DOI: $10.22630 /$ PRS.2020.20.1.7

Zalewski A. (2020). Changes in the Value of Used Fertilizers and Plant Protection Products in the Countries of the European Union in the Years 2010-2018 (in Polish). Problems of World Agriculture, 20(1), 78-87; DOI: 10.22630/PRS.2020.20.1.7 